\title{
STUDY OF THE IMPACT OF THE MOTOR CHARACTERISTICS OF SPEED ON THE AGE PECULIARITIES
}

\author{
Dilyana Nancheva, Korneliya Naydenova
}

National Sports Academy „Vassil Levski“, Sofia, Bulgaria

\begin{abstract}
The motor quality of speed is defined by some authors as conservative related to its impact which involves the use of specific means and methods to influence its development. The selection of such means and methods depends on the age peculiarities performance which is mainly a consequence of its genetic predetermination. The main factor for exerting effective influence on the development of speed in school age is defining the age peculiarity impact of the quality and the specific changes in the growth in age aspect.

Based on the above-mentioned facts, the aim of the current study is to trace the changes and their impact on the speed quality with schoolboys via a 30-metre-race test. In order to achieve the aim, we set the following tasks:

1. Reading about the problem in scientific sources.

2. Processing the results of the 30-metre-race test of the boys whose personal data were taken for the research project, performed in 2018.

3. Revealing the impact peculiarities of the speed quality with schoolboys in the aspect of age.

We fulfilled our study tasks by statistic processing the achievements of the boys aged $6-18$ from 28 schools in 22 towns in the country, having participated in the 30-metre-race test. We applied a variation and comparative analysis which allowed us to specify the impact peculiarities of the motor quality in its age aspect.

After processing and analyzing the results of the study we found a lot of changes in the speed performance with schoolboys. These changes showed different periods of intense development of the quality, based on the increased results among the different ages. On the grounds of the above-mentioned results we recommend the use of specific means and methods to improve the effect on speed in school age.
\end{abstract}

Key words: motor quality, schoolboys, physical activity

\section{INTRODUCTION}

Examining motor characteristics through physical education necessiates a specific view to the problem to make it possible to draw conclusions and give recommendations to help teachers with their work in the school subject and to have a big effect on the educational process. In this meaning, one of the significant problems is clarification of the periods of growth and natural ontogenetic development of the motor characteristics. This could help teachers to plan their work for the motor characteristics during the 12-year school period.

A similar statement is substantiated by the opinion of a number of experts who initially clarify the ways of manifestation, development and developing the motor characteristics. Thus for example, of physical at the end of last century (Balic, 1974; Guba, Nikitushkin, Kvashuk, 1997; Zatsiorski, 1970) claim that the base structure of development of motor characteristics is connected with progressive morpholog- ical and biochemical changes in the locomotor system, central and peripheral nerve system and the internal organs, i.e. the development characteristics depends on the coordination between somatotype and vegetative functions.

A number of authors like (Fomin, Filin, 1975; Zatsiorski, 1970; Rachev, 1971; Dimitrova, 1991; Zhelyazkov, 1998; Yordanova, 2008 etc.) have written about speed and clarifying the age structure of its manifestation. Zhelyazkov and Dasheva, summarizing the numerous authors' conclusions, claim that the period from 7-8 to 13-14 years of age is the most suitable for developing the quality of speed.

\section{Aim and objectives of the study}

Based on the above-mentioned facts, the aim of the current study is to trace the changes and their impact on the speed quality with schoolboys via a 30-metre-race test. In order to achieve the aim, we set the following tasks: 
1. Reading about the problem in scientific sources.

2. Processing the results of the 30-metre-race test of the boys whose personal data were taken for the research project, performed in 2018.

3. Revealing the impact peculiarities of the speed quality with schoolboys in the aspect of age.

Based on the books about the aims and objectives of the study we set the examination of the state of the motor quality of speed with schoolboys between the age of 6 and 18 as the subject. The object of the study is the changes that happen in the man- ifestation of the motor quality with students over the 12 -year period.

\section{METHODS}

The study was conducted in the autumn in 2018 as part of a project on establishing the level of physical capacity of the students in the country. The results, processed and analyzed in this article, reflect the achievements of 4,172 schoolboys aged 6-18 from 28 schools in 22 towns in the country. Table 1 gives a detailed classification according to the age of the studied contingent.

Table 1. Contingent of the survey

\begin{tabular}{|c|c|c|c|c|c|c|c|c|c|c|c|c|c|}
\hline Age & 6 & 7 & 8 & 9 & 10 & 11 & 12 & 13 & 14 & 15 & 16 & 17 & 18 \\
\hline Count & 42 & 352 & 370 & 396 & 397 & 487 & 455 & 390 & 287 & 317 & 275 & 238 & 166 \\
\hline
\end{tabular}

All 4,172 students were subjected to the test of asymmetry (As) and excess (Ex) indicators, we find 30 -metre high start running. We processed the results using the software product SPSS.20. We also subjected the results to a variational and comparative analysis.

\section{RESULTS}

We will start the analysis of the obtained results by interpreting the values of the indicators of the variational analysis. Considering the values of the that there is no normal distribution of achievements, except for the group of 6-year-old students. These values allow us to apply non-parametric statistical criteria in subsequent comparisons. We are also interested in the sign in front of the value of the asymmetry indicator. The negative value of this indicator with 18-year-old boys in Table 2 makes a clear impression that the achievements are concentrated around the minimum.

Table 2. Indicators of variational analysis

\begin{tabular}{|c|c|c|c|c|c|c|c|c|c|}
\hline Age & $\mathbf{n}$ & $\mathbf{R}$ & $\mathbf{X m i n}$ & $\mathbf{X m a x}$ & $\mathbf{X}$ & $\mathbf{V \%}$ & $\mathbf{s}$ & $\mathbf{A s}$ & $\mathbf{E x}$ \\
\hline $\mathbf{6}$ & 42 & 3.60 & 5.510 & 9.110 & 7.307 & 9.96 & 0.728 & 0.222 & 0.684 \\
\hline $\mathbf{7}$ & 352 & 6.20 & 4.550 & 10.750 & 7.232 & 12.5 & 0.904 & 0.812 & 1.283 \\
\hline $\boldsymbol{8}$ & 370 & 5.85 & 4.600 & 10.450 & 6.744 & 12.42 & 0.838 & 0.747 & 1.605 \\
\hline $\mathbf{9}$ & 396 & 5.67 & 4.280 & 9.950 & 6.358 & 12.39 & 0.788 & 0.660 & 1.982 \\
\hline $\mathbf{1 0}$ & 397 & 4.58 & 4.520 & 9.100 & 6.167 & 10.75 & 0.663 & 0.946 & 2.102 \\
\hline $\mathbf{1 1}$ & 487 & 4.94 & 4.260 & 9.200 & 5.974 & 11.61 & 0.694 & 1.181 & 2.804 \\
\hline $\mathbf{1 2}$ & 455 & 3.75 & 4.370 & 8.120 & 5.731 & 10.99 & 0.630 & 0.862 & 0.906 \\
\hline $\mathbf{1 3}$ & 390 & 5.03 & 4.110 & 9.140 & 5.484 & 11.54 & 0.633 & 1.146 & 2.816 \\
\hline $\mathbf{1 4}$ & 287 & 4.87 & 3.790 & 8.660 & 5.278 & 12.01 & 0.634 & 2.099 & 2.663 \\
\hline $\mathbf{1 5}$ & 317 & 6.71 & 3.790 & 10.500 & 5.181 & 13.68 & 0.709 & 0.852 & 10.461 \\
\hline $\mathbf{1 6}$ & 275 & 3.58 & 3.770 & 7.350 & 5.043 & 10.90 & 0.553 & 2.289 & 1.585 \\
\hline $\mathbf{1 7}$ & 238 & 4.86 & 4.010 & 8.870 & 4.930 & 12.19 & 0.601 & 1.097 & 10.279 \\
\hline $\mathbf{1 8}$ & 166 & 3.00 & 4.000 & 7.000 & 4.913 & 7.81 & 0.384 & -1.268 & 1.406 \\
\hline
\end{tabular}

The values of the coefficient of variation $(\mathrm{V} \%)$ presented in Table 2 and Figure 1 indicate that the achievements of the studied group are homogeneous or relatively homogeneous. In practical terms, this means that developing the motor quality of speed does not require differentiation or individ- ualization of the means and methods that are used to exert an influence on the children.

Contrary to the sources mentioned above, our study reveals a trend of continuous improvement in students' achievements according to age. The aver- 
age arithmetic means values presented in Figure 1 whole period is almost 2.5 seconds, varying from decrease with age increasing and at relatively steady 7.307 seconds with 6 -year old to 4.913 seconds with rates. The improvement of achievements over the 18-year-old boys.

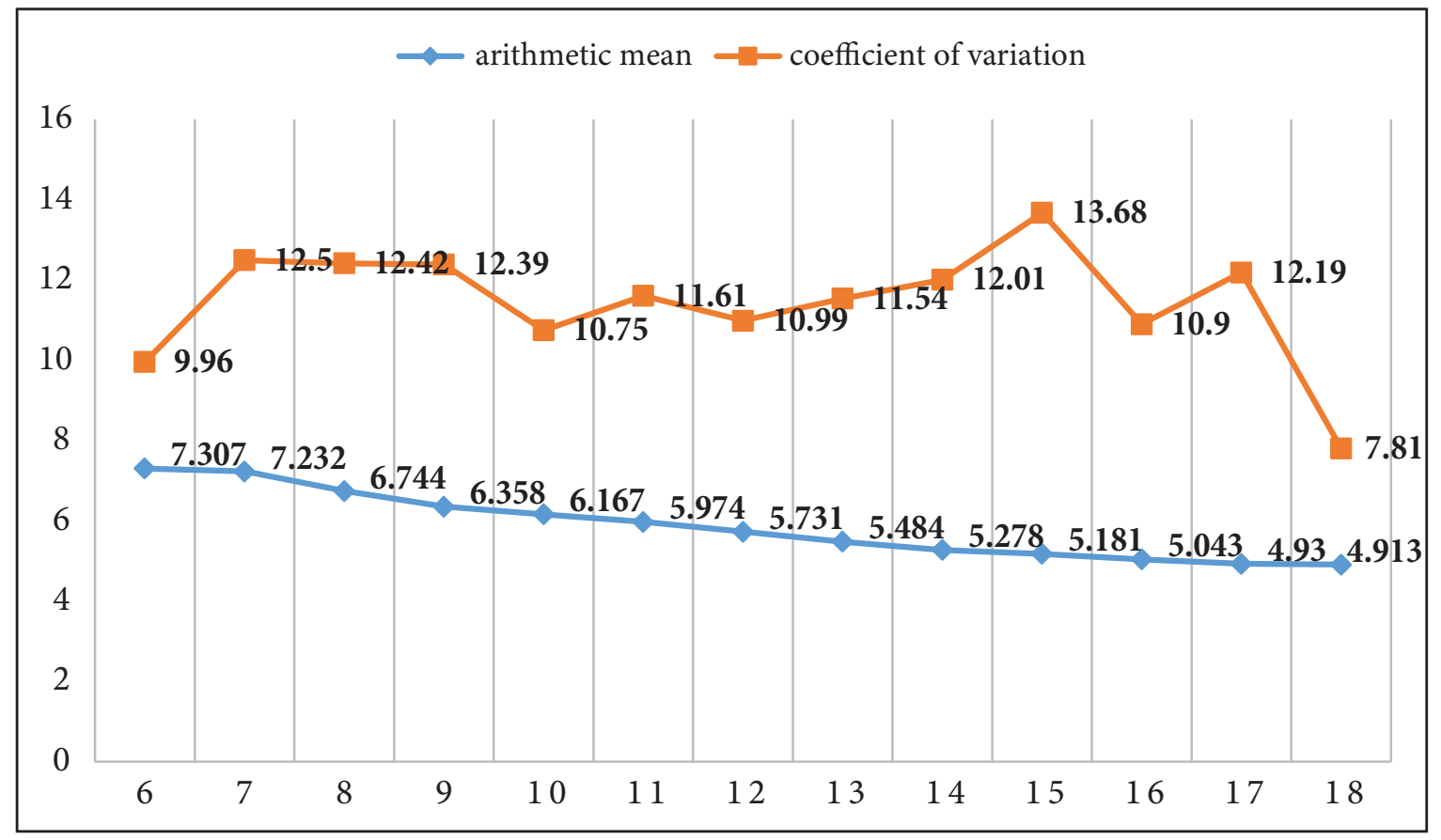

Figure 1. Values of arithmetic mean and coefficient of variation

To test the impact of the age factor on the achievements presented above, we subjected the results of the study to benchmarking using the Mann-Whitney test by consistently comparing the achievements by age. In most of the examined cases the values of the specified criteria and their corresponding reliability levels clearly indicate the influence of age characteristics on the achievements. Exceptions are the differences in achievement between 14 and 15, 15 and 16 and 17 and 18 years of age, where a is greater than the required 0.005 .

\section{DISCUSSION}

The analysis and interpretation of the results obtained from the study justify the following conclusions:

1.With boys of school age there is a trend of continuous improvement in age achievements at the test of 30-metre running, which carries information about the motor quality of speed.

2. The differences in achievement found in the various cases are a consequence of the peculiarities of age development.

3. In the cases of impact aimed at developing the motor quality of speed with students, it is not necessary to individualize and differentiate the applied means and methods in the separate groups.

\section{REFERENCES}

Dimitrova, S. (1991). Psihologo-pedagogichni podhodi pri vazrastovoto razvitie na podrazstvashtite. Sofia:NSA - Izdatelsko-pechatna baza // Димитрова, С. (1991). Психолого-педагогични подходи при възрастовото развитие на подрастващите. София: НСА - Издателско-печатна база.

Fomin, N., Filin, V. (1975). Vazrastovi osnovi na fizicheskoto vazpitanie. Sofia: Medicina i fizkultura // Фомин, Н., Филин, В. (1975). Възрастови основи на физическото възпитание. София: Медицина и физкултура.

Guba, V.P., Nikitushin, V.G., Kvashuk, P.V. (1997). Individualnie osobenosti unah sportsmenov. Smolensk: SGIFK // Губа, В.П., Никитушкин, В.Г., Квашук, П.В. (1997). Индивидуальньіе особенности юньіх спортсменов. Смоленск: СГИФК.

Jeliazkov, Tsv. (1998). Osnovi na sportnata trenirovka. Sofia: Uchebnik // Желязков, Ц. (1998). Основи на спортната тренировка. София: Учебник.

Jeliazkov, Tsv., Dasheva, D. (2002). Osnovi na sportnata trenirovka. Sofia. Gera Art // Желязков, Цв., Дашева, 
Д. (2002). Основи на спортната тренировка. София: Гера Арт.

Valik, B. (1974). Treneram unah lekoatletov. Moskva: FiS // Валик, Б. (1974). Тренерам юньіх лекоатлетов. Москва: ФиС.

Yordanova, N. (2008). Fizicheskite i koordinacionnite sposobnosti - faktori a sportnoto obuchenie na uchenicite. Shumen: Faber // Йорданова, Н. (2008). Физическите u координационните способности - фактори за спортното обучение на учениците. Шумен: Фабер.
Zociorski, V. (1970). Fizicheskite kachestva na sportista. Sofia. Medicinai i fizkultura // Зациорски, В. (1970). Физическите качества на спортиста. София: Медицина и физкултура.

\section{Corresponding autor:} Korneliya Naydenova

National Sports Academy „Vassil Levski“, Department of Theory of Physical Education, E-mail: knaidenova.nsa@gmail.com 